\title{
Ethanolic Extract of Capparis decidua Fruit Ameliorates Methotrexate-Induced Hepatotoxicity by Activating Nrf2/HO-1 and PPAR $\gamma$ Mediated Pathways
}

\author{
Preetha Santhakumar ${ }^{1, *}$, Anitha Roy ${ }^{2}$, Karthik Ganesh Mohanraj ${ }^{3}$, Selvaraj Jayaraman ${ }^{4}$, \\ Rajkumar Durairaj ${ }^{5}$
}

${ }^{1}$ Department of Physiology, Saveetha Dental College and Hospitals, Saveetha Institute of Medical and Technical Sciences, Chennai, Tamil Nadu, INDIA.

2Department of Pharmacology, Saveetha Dental College and Hospitals, Saveetha Institute of Medical and Technical Sciences, Chennai, Tamil Nadu, INDIA.

${ }^{3}$ Department of Anatomy, Saveetha Dental College and Hospitals, Saveetha Institute of Medical and Technical Sciences, Chennai, Tamil Nadu, INDIA.

${ }^{4}$ Department of Biochemistry, Saveetha Dental College and Hospitals, Saveetha Institute of Medical and Technical Sciences, Chennai, Tamil Nadu, INDIA.

${ }^{5}$ Department of Anatomy, National Institute for Empowerment of Persons with Multiple Disabilities, Muttukadu, Chennai, Tamil Nadu, INDIA.

\begin{abstract}
Introduction: Methotrexate, a folate antimetabolite, immunosuppressant and cytotoxic chemotherapeutic agents employed for malignant conditions. Continuous exposure of methotrexate produces adverse side effects especially liver toxicity. Recently, medicinal plants are gaining an importance owing to their phytoconstituents which are responsible for their medicinal value. Capparis decidua is one such medicinal plant widely used in the traditional system of medicine. No study has focused the mechanism of hepatoprotective property of Capparis decidua via Nrf2/HO-1 and PPAR $\gamma$ signaling pathway. Hence the study was mainly focused on its ability to modulate Nrf2 and PPAR $\gamma$ signaling in the methotrexate induced hepatotoxicity in Wistar rats. Materials and Methods: 30 female Wistar albino rats were divided into five groups. Following a single dose of methotrexate $(20 \mathrm{mg} / \mathrm{kg}$, intraperitoneally) injection, Wistar rats were orally administered with Capparis decidua at a doses of $250 \mathrm{mg} / \mathrm{kg}$ and $500 \mathrm{mg} / \mathrm{kg}$ for 14 days. AST, ALT and ALP, antioxidants like GST, GPx, GR, were assessed in hepatic tissue. $\mathrm{LPO}, \mathrm{H}_{2} \mathrm{O}_{2}, \mathrm{OH}$ radicals were assessed. mRNA expression of Nrf2, HO-1, PPARY was carried using real-time PCR in hepatic tissue. Nrf2, TNF- $\alpha$, IL $-1 \beta$ proteins were assessed using western blot. Results: Methotrexate administration significantly increased liver function marker, caused lipid peroxidation and decreased antioxidants levels. Treatment with Capparis decidua caused significant decrease in AST, ALT, ALP, levels and significant increase in GST, GPx, GR. Methotrexate decreased mRNA expression of Nrf2, HO-1, PPAR $\gamma$. Capparis decidua prevented methotrexate induced liver injury by upregulating Nrf2 and PPARY signaling pathway. Capparis decidua also suppressed inflammatory markers like TNF- $\alpha$ and IL $-1 \beta$ proteins. Conclusion: Capparis decidua has thus attenuated methotrexate induced hepatotoxicity and this could be via up-regulation of Nrf2/HO-1 and PPAR $\gamma$ pathways.
\end{abstract}

Key words: Antioxidant, Capparis decidua, Hepatotoxicity, Methotrxate, Nrf2, PPARY.

\section{INTRODUCTION}

The vital organ of metabolism is liver and it is very important for maintaining homeostasis. Also it is essential for detoxification of drugs and they are easily exposed to xenobiotics and hence are easily susceptible to the damage by these drugs. ${ }^{1}$ Drug induced liver injury caused by medications and toxins, a common cause of acute liver failure is one of the most leading causes of non-approval and drug withdrawal
Submission Date: 24-09-2020; Revision Date: 15-12-2020; Accepted Date: 03-02-2021

DOI: 10.5530/ijper.55.1s.59 Correspondence: Dr. Preetha S

Department of Physiology, Saveetha Dental College and Hospitals, Saveetha Institute of Medical and Technical Sciences, Chennai-600077, Tamil Nadu, INDIA. Phone no: +91-08608566435 Email id:drpreeth.homeo@ gmail.com

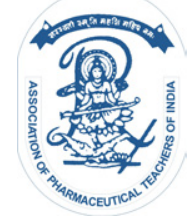

www.ijper.org 
from the market. ${ }^{2,3}$ The drug induced liver damage can progress to hepatocellular death, hepatitis and acute liver failure. ${ }^{4}$ Methotrexate is a folate antimetabolite, immunosuppressant and cytotoxic chemotherapeutic $\operatorname{drug}^{5}$ and it is a drug mainly employed in high doses for malignant conditions. ${ }^{6}$ It is an inhibitor of dihydrofolate reductase and it is used widely to treat various diseases like oncological disorders, rheumatological, inflammatory, dermatological conditions. ${ }^{7-9}$ Also it is a very important drug of choice for rheumatoid arthritis and psoriasis. ${ }^{10}$

However, Continuous exposure to methotrexate produces adverse side effects especially liver toxicity. ${ }^{11}$ But the exact mechanism underlying the methotrexate induced hepatotoxicity has not been understood clearly and one of the proposed mechanisms for hepatotoxicity induced by methotrexate is oxidative stress and diminished levels of antioxidants. ${ }^{12,13}$ Methotrexate has been found to have a negative action on machinery of mitochondria which in turn produces ROS. ${ }^{14,15}$ The ROS in turn induces cellular damage causing peroxidation of lipids leading to cell death. ${ }^{16}$ Along with excess production of reactive oxygen species/ reactive nitrogen species, reduced antioxidant defence mechanism also promotes the development of hepatotoxicity. ${ }^{17}$ Hence the proper way of dealing with the oxidative stress and its attenuation would represent an appropriate method to prevent against hepatotoxicity induced by methotrexate.

Nrf2, which is Nuclear factor erythroid derived -2 is basic leucine zipper (bZIp) protein that confers protection against oxidative stress by regulating the antioxidant defense proteins expression in the cell. Under normal circumstances, Nrf2 is anchored by Keap 1 (Kelch like Ech associated proten 1 ) in the cytoplasm. ${ }^{18}$ When exposed to oxidative damage, Nrf2 is released into the nucleus where it combines with ARE (antioxidant response element) in the DNA promoter gene by which it causes initiation of transcription of antioxidant genes which includes (HO) - 1 ( Hemeoxygenase), NQO-1 (NADPH quinoneoxidoreductase, SOD, catalase and other antioxidant genes. ${ }^{19}$ Thus activation of Nrf2 signalling pathway confers protection against oxidative stress induced by drugs and other agents. ${ }^{14,19,20}$ These findings indicate the very important role of $\mathrm{Nrf} 2$ in combating the drug toxicity mainly by increasing the cellular antioxidant defense mechanism.

Recently, PPARY (Peroxisome proliferator activated receptor gamma has gained importance and proposed to play a very important role against liver injuries caused by drugs. ${ }^{14,21,22}$ The activation of PPARY produces anti-inflammatory effects and modulates the number of antioxidant gene expressions. ${ }^{23}$ Thus activation of PPAR $\gamma$ would be one of the effective strategies to target oxidative stress induced by drugs. Since reactive oxygen species are implicated behind the pathogenesis of hepatotoxicity induced by methotrexate, supplementation of compounds or drugs rich in antioxidants can be considered one of the alternative methods to combat hepatotoxicity.

Recently, medicinal plants are gaining a significant role in pharmaceutical industries owing to their phytoconstituents which are responsible for their medicinal value in curing diseases. ${ }^{24}$ Capparis decidua is one such medicinal plant widely used in the traditional system of medicine. It belongs to the family Capparidaceae. It is a xerophytic shrub found widely in North western parts of India. It is rich in phytochemicals such as stigmasterol, rutin, quercetin, spermidine, tocopherols, carotenoids, kaempferol, campesterol,. it also possess many pharmacological properties such as antiviral, antibacterial, immunomodulatory, antimicrobial, anti-oxidative, anti-inflammatory properties, hepatoprotective property. ${ }^{25-27}$ Hepatoprotective effects of aqueous and methanolic extract of Capparis decidua stem against $\mathrm{CCl}_{4}$ induced hepatotoxicity have been studied previously. ${ }^{27}$ But there are no studies of ethanolic extract of Capparis decidua fruit against methotrexate induced hepatotoxicity. Also no study has focused the mechanism of hepatoprotective property via $\mathrm{Nrf} 2 / \mathrm{H} 0$ 1 signaling pathway. Hence the aim of the current study is to elucidate the protective effect of Capparis decidua fruit extract and to investigate the underlying action and the study was mainly focused on its ability to modulate Nrf2 and PPAR $\gamma$ signaling in the methotrexate induced hepatotoxicity in Wistar rats.

\section{MATERIALS AND METHODS}

\section{Chemicals}

Methotrexate were purchased commercially belonging to Ipca Laboratories Private Limited-Mumbai, silymarin from Research-lab Fine Chem Industries, Mumbai. All chemicals and reagents used in this study were obtained from Sigma, St. Louis, USA and Sisco Research Laboratories, Mumbai, India. Other chemicals which were used for analysis of various assay were obtained locally and were of analytical grade

\section{Preparation of Ethanolic extract of Capparis decidua}

Fresh fruits of Capparis decidua were obtained, identified and authenticated by Botanist and it is double washed with running water and then dried under shade. The dried fruit was thoroughly ground to a fine powder 
using a blender. $100 \mathrm{gms}$ of ground powder was mixed with $500 \mathrm{ml}$ of ethanol which was then placed in shaker for $24 \mathrm{hr}$ and then it was subjected to boiling at $50^{\circ} \mathrm{C}$ with occasional stirring and it was filtered using filter paper and again subjected to boiling until concentrated extract was obtained and yielded around $20 \mathrm{gms}$ of ethanolic extract and the extract was then stored in a sterile container under $-20^{\circ} \mathrm{C} .{ }^{28}$

\section{Animals}

Healthy female Wistar albino rats weighing around 180 $\pm 20 \mathrm{~g}$ were used for the study. The animals were kept under standard temperature $\left(21 \pm 2^{\circ} \mathrm{C}\right)$, under specific humidity, constant $12 \mathrm{~h}$ dark and $12 \mathrm{~h}$ light cycle as per National guidelines. The animals were maintained under sterilized paddy husk as bedding material in polypropylene cages and were fed with pellet and water ad libitum. And the study protocol received approval from IAEC (IAEC No. BRULAC/SDCH/SIMATS/ IAEC/12-2019/037).

\section{Experimental protocol}

Thirty adult female albino rats of Wistar strain with 180 $\pm 20 \mathrm{~g}$ body weight were randomly divided into five groups with six animals in each group. Group I animals serve as a control group and receive normal saline for a period of 14 days. Group II served as a methotrexate group which received methotrexate injection $20 \mathrm{mg} / \mathrm{kg}$ body weight on the first day intraperitoneally followed by normal saline for a period of 14 days following IP methotrexate injection on the first day. Dose of methotrexate was fixed based on previous study. ${ }^{29}$ Group III served as methotrexate with Capparis decidua $250 \mathrm{mg} / \mathrm{kg}$ body weight group which received oral dose of ethanolic extract of Capparis decidua 250mg/ $\mathrm{kg}$ body weight for a period of 14 days, Group IV served as methotrexate with Capparis decidua $500 \mathrm{mg} /$ $\mathrm{kg}$ body weight group which received oral dose of ethanolic extract of Capparis decidua $500 \mathrm{mg} / \mathrm{kg}$ body weight for a period of 14 days. Ethanolic extract of Capparis decidua was dissolved in water for oral administration to the wistar rats. Group V served as methotrexate with Silymarin group which received oral dose of Silymarin $100 \mathrm{mg} / \mathrm{kg}$ body weight in $0.5 \%$ CMC (positive control) for a period of 14 days following IP injection of methotrexate on the first day. Dose of Capparis decidua was decided based on the previous study. ${ }^{30}$ Dose of silymarin (standard hepatoprotective agent) was decided based on previous literature. ${ }^{31}$ On the $15^{\text {th }}$ day, the animals were anesthetized with sodium thiopentone ( $40 \mathrm{mg} / \mathrm{kg}$ body weight). The blood was collected by cardiac puncture. The serum obtained was separated and stored under standard condition. Liver tissues were immediately dissected, weighed and stored at under standard temperature for analysis of various biochemical assays.

\section{Biochemical assay Liver function markers}

Liver function test markers like ALT (Alkaline transaminase), AST (Aspartate Transaminase), ALP (Alkaline Phosphatase), were determined in serum using biochemical-assay, obtained from Spinreact, Spain. values were expressed in IU/L.

\section{Lipid peroxidation}

Lipid peroxidation (LPO) was measured in liver tissue homogenate as in accordance to the study by Devasagayam and Tarachand. ${ }^{32}$ The malondialdehyde (MDA) content was expressed as nmoles of MDA formed $/ \mathrm{min} / \mathrm{mg}$ protein. Hydrogen peroxide generation was done in accordance to the method of Pick and Keisari ${ }^{33}$ and the values were expressed in $\mu \mathrm{moles} / \mathrm{min} / \mathrm{mg}$ protein. For quantification of hydroxyl radical $\left(\mathrm{OH}^{*}\right)$, Puntarulo and Cederbaum, ${ }^{34}$ method was used and values were expressed in the form of $\mu$ moles per min per mg protein.

\section{Antioxidant enzymes}

Rotruck et al. ${ }^{35}$ method was used to assess GPx and the activity was expressed as $\mu \mathrm{g}$ of utilized glutathione / per min per mg protein in liver tissue homogenate. The method of Habig et al. ${ }^{36}$ was used to assess GlutathioneS-transferase (GST) activity and values were expressed in the form of $\mu$ moles of $\mathrm{CDNB}$ utilized per min per mg protein. The method of Staal et al. ${ }^{37}$ was used to analyse Glutathione reductase (GR) and values for activity of GR and GSH were expressed in the form of nmoles of GSSG reduced per min per mg protein and nmoles of GSH per mg protein respectively.

\section{mRNA expression analysis for Nrf2, HO-1, PPARY Total RNA isolation}

In the present study, we isolated total RNA by total RNA isolation reagent kit (TRIR, invitrogen). Briefly, $100 \mathrm{mg}$ fresh tissue from control and treated animals were added to $1 \mathrm{ml}$ of TRIR and homogenized. After, homogenization, $0.2 \mathrm{ml}$ of chloroform was added and mixed the contents by overtexing for $1 \mathrm{~min}$ and $\mathrm{kept}$ for $5 \mathrm{~min}$ at $4^{\circ} \mathrm{C}$. Then, it was centrifuged for $5 \mathrm{~min}$ at $12,000 \times \mathrm{g}$ for $15 \mathrm{~min}$ at $4^{\circ} \mathrm{C}$. Carefully, the upper aqueous phase was transferred carefully in to a fresh microfuge tube and isopropanol equal volume was added and placed on ice for 10 min after vortexing for $15 \mathrm{~S}$. The supernatant was discarded after centrifugation 
of the contents at $12000 \times \mathrm{g}$ for $10 \mathrm{~min}$ at $4^{\circ} \mathrm{C}$. After, the supernatant was discarded and by simple vortexing, the RNA pellet was washed with $1 \mathrm{ml}$ of $75 \%$ ethanol. The total RNA concentration was measured spectrophotometrically and the concentration was expressed in micrograms.

\section{cDNA conversion and real-time PCR analysis}

Complementary DNA (cDNA) conversion was carried out form $2 \mu \mathrm{g}$ total RNA using reverse transcriptase kit, as per the manufacturer instructions (Eurogentec, Seraing, Belgium). For the analysis of real-time PCR, the PCR reaction mix contacting $2 \mathrm{x}$ reaction buffer (Takara SyBr green master mix), target gene specific and internal control gene and water and cDNA in total volume of $45 \mu \mathrm{l}$ and spun down (the primer sequences were listed in Table 1). The reaction was set up for 40 cycles $\left(95^{\circ} \mathrm{C}\right.$ for $5 \mathrm{~min}, 95^{\circ} \mathrm{C}$ for $5 \mathrm{~s}, 60^{\circ} \mathrm{C}$ for $20 \mathrm{~s}$ and $72^{\circ} \mathrm{C}$ for $40 \mathrm{~s}$ ). The results were obtained and plotted by the PCR machine (CFX96 Touch Real-Time PCR Detection System) on a graph. Melt and amplification were used for quantification.

\section{Protein expression analysis Protein Isolation}

In a buffer-A containing $100 \mathrm{mg}$ tissues from control and treated animals were homogenized and centrifuged for $10 \mathrm{~min}$ at $4^{\circ} \mathrm{C}$ at $1300 \mathrm{xg}$ for $10 \mathrm{~min}$ at $4^{\circ} \mathrm{C}$. After centrifugation, the supernatant was used as a total protein for the estimation of Nrf2, TNF- $\alpha$, IL $-1 \beta$.

\section{Western blot analysis}

The proteins were separated on $10 \%$ gel by sodium dodecyl sulfate-polyacrylamide gel electrophoresis (SDS-PAGE). Briefly, tissue lysate proteins (50 $\mu \mathrm{g} / \mathrm{lane}$ ) were separated electrophoresed and transferred on polyvinylidenedifluoride (PVDF) membrane (Bio-Rad Laboratories Inc). The membranes were then blocked by $5 \%$ non-fat dry milk and then it was incubated in the

\begin{tabular}{|c|c|c|}
\hline $\begin{array}{l}\text { Gene } \\
\text { name }\end{array}$ & Forward primer $\left(5^{\prime}-3^{\prime}\right)$ & $\begin{array}{c}\text { Reverse primer } \\
\left(5^{\prime}-3^{\prime}\right)\end{array}$ \\
\hline Nrf2 & $\begin{array}{c}\text { TTGTAGATGACCATGA } \\
\text { GTCGC }\end{array}$ & $\begin{array}{l}\text { TGTCCTGCTGTAT } \\
\text { GCTGCTT }\end{array}$ \\
\hline $\mathrm{HO}-1$ & $\begin{array}{c}\text { GTAAATGCAGTGTTG } \\
\text { GCCCC }\end{array}$ & $\begin{array}{l}\text { ATGTGCCAGGCAT } \\
\text { СTCСTTC }\end{array}$ \\
\hline PPARY & $\begin{array}{c}\text { GGACGCTGAAGAAGA } \\
\text { GACCTG }\end{array}$ & $\begin{array}{l}\text { CCGGGTCCTGTCT } \\
\text { GAGTATG }\end{array}$ \\
\hline GAPDH & $\begin{array}{c}\text { TGGATTTGGACGCAT } \\
\text { TGGTC }\end{array}$ & $\begin{array}{c}\text { TTTGCACTGGTACG } \\
\text { TGTTGAT }\end{array}$ \\
\hline
\end{tabular}

primary antibodies (1:1000 dilutions) for overnight. After, the membrane was washed with Tris-buffered saline Tween-20 (TBS-T) and incubated for $1 \mathrm{~h}$ in horseradish peroxidase-conjugated secondary antibody (1:10000 dilution) and the specific signals were using enhanced chemiluminescence detection systems (Thermo Fisher scientific Inc, USA), the specific signals were detected using Chemidoc and quantified by Quantity One image analysis system (Bio-Rad Laboratories, CA). After, the protein bands were captured. As the invariant control in the present study, we used rat $\beta$-actin.

\section{Statistical analysis}

Data were expressed as mean \pm S.E.M and analyzed by one-way analysis of variance followed by Tukey's post hoc analysis multiple comparison test to determine the significance of differences between groups using Graphpad prism software. A $p$-value less than 0.05 was considered as showing significant difference.

\section{RESULTS}

\section{Effects of Capparis decidua on liver function in hepatic tissue}

As seen in Figure 1, liver function markers like ALT levels, AST levels and ALP levels were increased significantly in the methotrexate induced group of animals when compared to the control group of animals $(p<0.001)$. Oral administration of Capparis decidua at a dose of 250 $\mathrm{mg} / \mathrm{kg}$ has significantly reduced methotrexate-induced

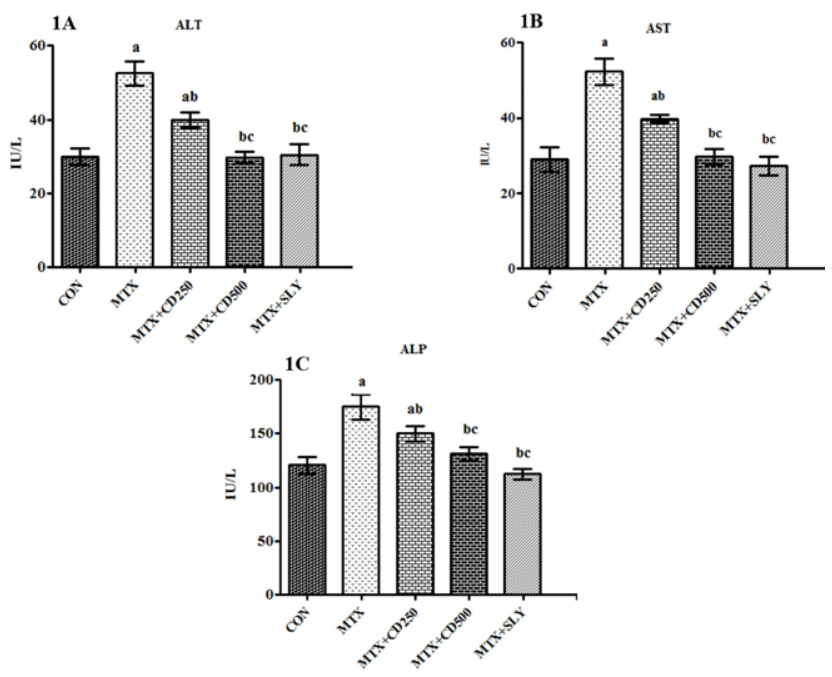

Figure 1(A, B, C): Effect of treatment with CD on AST, ALT and ALP levels in MTX-induced hepatotoxicity. Data are represented as means \pm SD. Data were analyzed by oneway ANOVA followed by Tukey's post hoc test for multiple comparisons. a - compared with the control, b compared with methotrexate induced group, c - compared with CD 250 treated group. 
increase in AST levels, ALT levels and ALP levels ( $p$ $<0.01$ ) (Figure $1 \mathrm{a}, \mathrm{b}$ and $\mathrm{c}$ ). Oral administration of Capparis decidua extract at a dose of $500 \mathrm{mg} / \mathrm{kg}$ for a period of 14 days has reduced methotrexate-induced increase in all liver function parameters i.e AST levels, ALT levels and ALP levels $(p<0.001)$ significantly. The result was comparable with the silymarin.

\section{Effects of Capparis decidua on lipid peroxidation}

In group II rats, administration of IP injection of methotrexate produced a $(p<0.001)$ rise in the level of Lipid peroxidation, $\mathrm{H}_{2} \mathrm{O}_{2}, \mathrm{OH}$ radical when compared with control group of rats while group III rats, oral administration of with Capparis decidua $250 \mathrm{mg} / \mathrm{kg}$ extract showed a $(p<0.001)$ reduction in the levels of LPO $(p<0.01), \mathrm{H}_{2} \mathrm{O}_{2}(p<0.05), \mathrm{OH}$ radical $(p<0.05)$ in the hepatic tissue of rats significantly. Groups of rats namely IV and V, administered with Capparis decidua $500 \mathrm{mg} / \mathrm{kg}$ and Silymarin, has caused a fall in the levels $(p<0.001)$ significantly compared with methotrexate administered group of rats (Figure $2 \mathrm{a}, \mathrm{b}, \mathrm{c}$ )

\section{Effects of Capparis decidua on antioxidants}

Figure 3 (a, b and $\mathrm{c}$ ) shows the effect of Capparis decidua on the antioxidants like GST, GPx, GR content in hepatic tissue. Administration of methotrexate has decreased GST, GPx and glutathione reductase content significantly when compared with the normal animals (all $p<0.001$ ). Oral administration of Capparis decidua
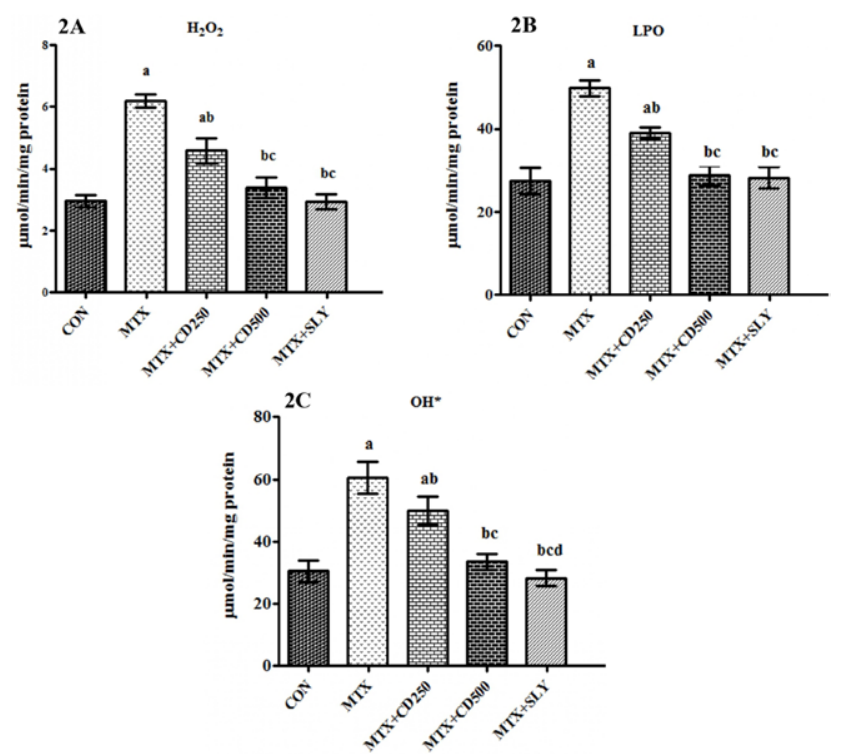

Figure 2(A, B, C): Effect of CD on $\mathrm{H}_{2} \mathrm{O}_{2}, \mathrm{OH}$, LPO radical in liver tissue of methotrexate intoxicated rats. Data are represented as means \pm SD. Data were analyzed by oneway ANOVA followed by Tukey's post hoc test for multiple comparisons. (mtx - methotrexate, CD - Capparis decidua). a - compared with the control, b compared with methotrexate induced group, c - compared with CD 250 treated group.
$250 \mathrm{mg} / \mathrm{kg}$ has increased these levels of GST levels $(p<$ 0.001), GPx levels ( $p<0.01)$, GR levels $(p<0.01)$ when compared with the methotrexate induced group of animals and it was statistically significant. Treatment with Capparis decidua $500 \mathrm{mg} / \mathrm{kg}$ has significantly increased the levels of Glutathione S Transferase, Glutathione peroxidase, glutathione reductase levels when compared
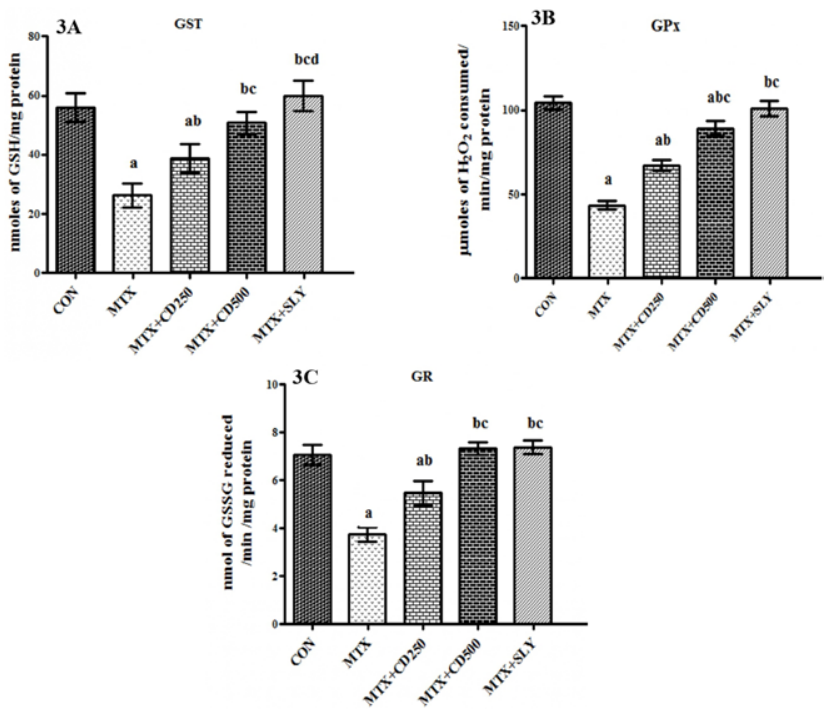

Figure 3 (A, B, C): Effect of CD on GST, GPx, GR in liver tissue of methotrexate intoxicated rats. Data are represented as means \pm SD. Data were analyzed by one-way ANOVA followed by Tukey's post hoc test for multiple comparisons. (mtx methotrexate, $C D$ - Capparis decidua). a - compared with the control, b compared with methotrexate induced group, c compared with CD 250 treated group.
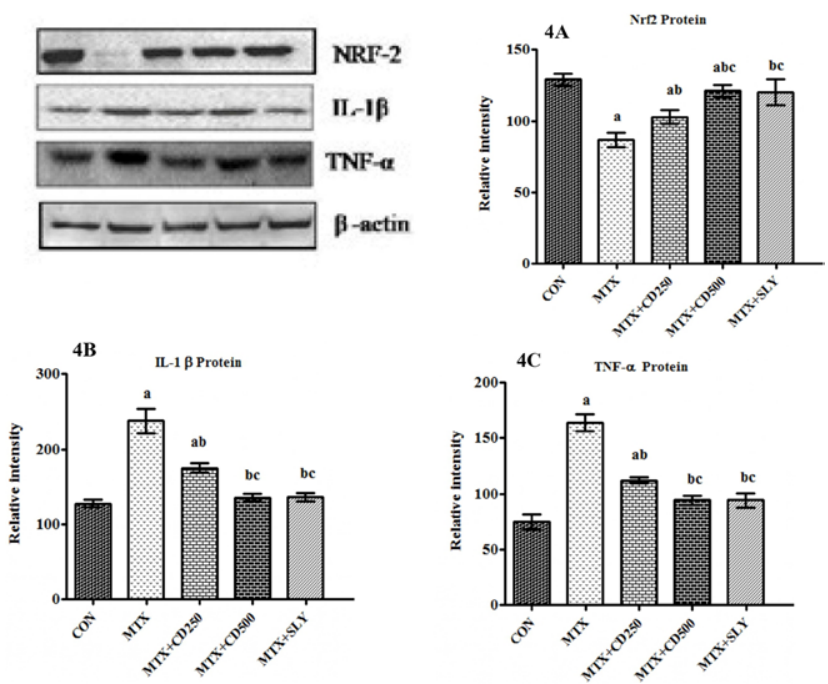

Figure 4 (A, B, C): Represents effect of CD on Nrf2, TNf alpha, IL $-1 \beta$ in liver tissue of methotrexate intoxicated rats. Data are represented as means \pm SD. Data were analyzed by oneway ANOVA followed by Tukey's post hoc test for multiple comparisons. ( $\mathrm{mtx}$ - methotrexate, CD - Capparis decidua). a - compared with the control, b compared with methotrexate induced group, c - compared with CD 250 treated group. 
with the methotrexate administered group of animals $(p$ $<0.001$ ) (Figure $3 \mathrm{a}-\mathrm{c}$ ).

\section{Effect of Capparis decidua on mRNA expression of Nrf2, HO-1, PPARY}

As shown in Figure 4 a, b, c the administration of methotrexate revealed significant decrease in the both mRNA of Nrf2, HO-1, PPARY in hepatic tissue when compared with the control group of animals $(p<0.001)$ and it was statistically significant, whereas Capparis decidua 250 and significantly caused up regulation of mRNA expression of Nrf2 levels $(p<0.001)$, HO-1 levels $(p<0.001)$ and it was highly significant statistically but there was decrease in PPARY but it was not statistically significant $(p>0.05)$ when compared with the methotrexate administered group Capparis decidua 500 significantly caused up regulation of mRNA expression of Nrf2, HO-1, PPAYY, compared with the methotrexate administered group of rats $(p<0.001)$ (Figure $5 \mathrm{a}-\mathrm{c}$ ).

\section{Effects of Capparis decidua on Nrf2, TNF-a, IL -1 $\beta$}

As shown in Figure $4 \mathrm{a}, \mathrm{b}, \mathrm{c}$ the administration of methotrexate caused reduction in the levels of protein Nrf2 significantly and elevation in the TNF- $\alpha$ and IL $-1 \beta$ levels in hepatic tissue when compared to the control group, whereas Capparis decidua 250 and 500 significantly caused significant increase in Nrf2 levels $(p<0.001)$ and caused down regulation of protein TNF- $\alpha$ and IL $-1 \beta$
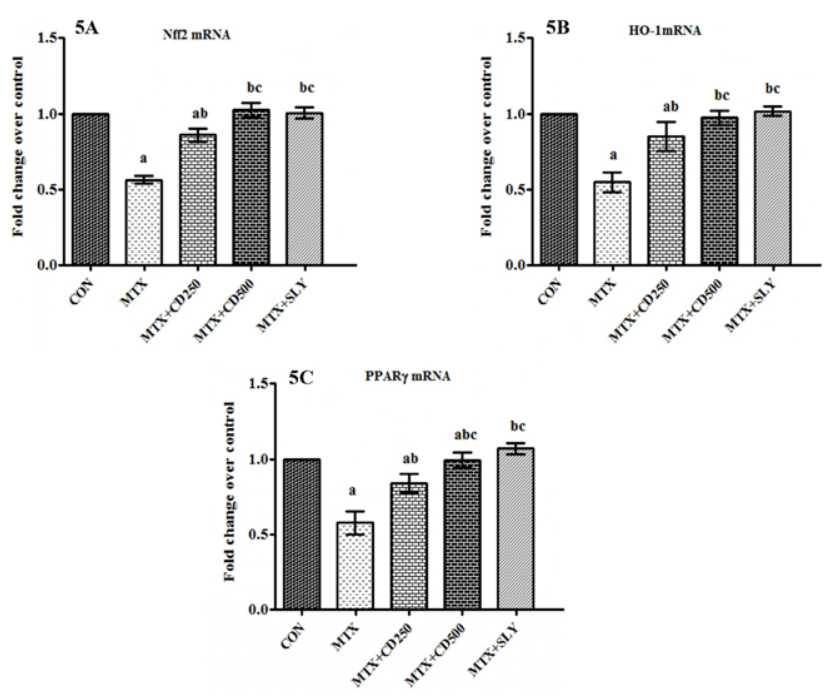

Figure 5: (A,B,C,D) Represents effect of CD on mRNA of Nrf2, HO, PPAY gamma in liver tissue of methotrexate intoxicated rats. Data are represented as means \pm SD. Data were analyzed by one-way ANOVA followed by Tukey's post hoc test for multiple comparisons. (mtx - methotrexate, CD - Capparis decidua). $\mathrm{a}$ - compared with the control, b compared with methotrexate induced group, c - compared with CD 250 treated group. in hepatic tissue when compared with the methotrexate administered group of rats $(p<0.001)$ (Figure 4 a-c).

\section{DISCUSSION}

It is an important medicinal plant used to cure jaundice and other liver disorders in the traditional system of medicine. ${ }^{27}$ The present study is an attempt to study its effect against methotrexate induced hepatotoxicity with special attention focusing on effect on Nrf2 signaling pathway. Methotrexate is a widely used anticancer immunosuppressant drug having its clinical application on diseases like acute lymphoblastic leukaemia, rheumatoid arthritis, ectopic pregnancy, crohn's disease, psoriasis, psoriatic arthritis, ulcerative colitis. ${ }^{38,39}$ Study shows that methotrexate increased levels of liver function markers like Alkaline transaminase, Aspartate Transaminase, Alkaline Phosphatase indicating liver damage with the previous study. ${ }^{40}$ methotrexate induces liver damage through production of ROS leading to oxidative stress and also interferes with antioxidant defence mechanism. ${ }^{41}$ The present study showed that the methotrexate administration induced the lipid peroxidation which was shown by increase in parameters like $\mathrm{H}_{2} \mathrm{O}_{2}, \mathrm{NO}$, TBARS levels in hepatic tissue. This was in accordance to the previous study which has also shown the elevated markers of lipid peroxidation. ${ }^{42,43}$ Our study showed that the administration of Capparis decidua fruit extract has effectively reduced hepatic levels of ALT, AST and ALP indicating its protective effect against liver damage induced by methotrexate. This was in accordance with the study ${ }^{27}$ (Ali et al. 2009) which also showed that Capparis decidua stem extract reducing the liver function markers in $\mathrm{CCl}_{4}$ induced hepatotoxicity. Administration of Capparis decidua ethanolic extract in methotrexate induced rats has reduced the elevated levels of lipid peroxidation markers like $\mathrm{H}_{2} \mathrm{O}_{2}, \mathrm{NO}$, TBARS. The presence of antioxidants in Capparis decidua ${ }^{44}$ could be responsible for attenuating lipid peroxidation induced by methotrexate. Previously it was studied that Capparis decidua fruit extract was found to be effective against alloxan induced lipid peroxidation (LPO) in erythrocyte, tissues of heart and kidney. ${ }^{45}$

Our present study also showed that the methotrexate administration caused significant reduction in GSH, GPX, GR, levels in hepatic tissue which was in accordance with the previous findings. ${ }^{46}$ It has been studied that methotrexate decreases the NADPH availability by inhibiting cytosolic nicotinamide adenosine diphosphate (NADP) dependent dehydrogenase and NADP malic enzyme, ${ }^{47} \mathrm{NADPH}$ is required to maintain the important cytosolic antioxidant glutathione, under 
reduced state, by the enzyme glutathione reductase. Methotrexate promotes significant reduction in glutathione levels (GSH) thereby sensitizing the cells to the action of reactive oxygen species. ${ }^{48,49}$ Glutathione peroxidase protects tissues from oxidative stress damage by converting hydrogen peroxide in the presence of GSH to water and disulfide glutathione (GSSG). GSSG formed as a result, will be converted back to GSH with the help of glutathione reductase. The present study also reported that administration of Capparis decidua fruit extract has replenished the levels of GSH, GPx, GR. This was comparable to the previous study by an author who showed that administration of Capparis decidua has promoted increase in levels of Gpx, GSH, GR reduced glutathione in renal and heart tissue of alloxan induced diabetic rats. ${ }^{50}$ However previously, there are no studies of Capparis decidua in methotrexate induced hepatotoxicity.

Previous studies have reported that methotrexate induced liver injury is attributed to inflammation. ${ }^{42,43}$ Our findings also revealed increased serum levels of protein tumour necrosis factor $\alpha$ and Interleukin $1 \beta$ levels in the methotrexate administered rats. This could be due to activation of $\mathrm{NFkB}$ signalling pathway ${ }^{51}$ which promotes activation of inflammatory markers. Capparis decidua prevented methotrexate induced inflammatory response which was shown by decrease in TNF $\alpha$ and IL- $1 \beta$ levels. This could be due to suppression of $\mathrm{NFkB}$ pathway by the presence of alkaloids, flavanoids, terpenes of the extract which suppresses the inflammatory proteins. The studies have shown that chloroform and methanolic extract of aerial parts of Capparis decidua possess potent anti-inflammatory activity against induced paw oedema in Swiss albino rats. ${ }^{52}$

To understand the mechanism behind the hepatoprotective effect of Capparis decidua against methotrexate, Nrf2/HO-1 and PPARY expression were studied. Nrf2 will be in a deactivated state in cytosol and it get separated from keap - 1, translocates to nucleus, activates the transcription of antioxidant gene by combining to ARE under situation of oxidative stress. ${ }^{52}$ PPARY is reported to protect against drug induced liver toxicity by supressing oxidative stress, inflammation and apoptosis. ${ }^{53,54}$ Our findings showed that the methotrexate administration down regulated the mRNA expression of $\mathrm{Nrf} 2$ and $\mathrm{Nrf} 2$ protein. It was confirmed by reduced expression of HO- 1 mRNA. ${ }^{22}$ Methotrexate administration also significantly downregulated mRNA expression of PPARY. Capparis decidua administration has upregulated the levels of Nrf2 m RNA, Nrf2 protein HO-1 mRNA expression and PPARY mRNA. This could be attributed to the presence of phytoconstituents of the extract which could be responsible for upregulation of Nrf2 and PPAR $\gamma$ pathway. No studies have focused the mechanism of hepatoprotective effects of Capparis decidua through Nrf2 and PPAR $\gamma$ pathway.

The present study has demonstrated that Capparis decidua, being a rich source of antioxidants confers protective effects against lipid peroxidation, oxidative stress, inflammation induced by methotrexate. This could be due to the presence of terpenoids, alkaloids, glycosides, flavonoids present in the extract which act as natural antioxidants and that could be responsible for increasing defense mechanisms against free radical production induced by methotrexate administration.

\section{CONCLUSION}

Thus, the extract has shown the promising biological activity against methotrexate induced hepatotoxicity. Capparis decidua fruit extract protected against hepatic damage, inflammation induced by methotrexate through up-regulation of Nrf2/HO-1 and PPAR $\gamma$ signaling pathways. Hepatoprotective effect of the Capparis decidua fruit is therefore attributed to its antioxidant effects.

\section{ACKNOWLEDGEMENT}

We sincerely thank Dr. Vijayaraghavan and Dr. E. Sukumar for their constant support. We would also like to thank Saveetha Dental College and Hospitals for their constant support in carrying out the research.

\section{CONFLICT OF INTEREST}

The authors declare that there is no conflict of interest.

\section{ABBREVIATIONS}

MTX: Methotrexate; ROS: Reactive oxygen species; Nrf2: Nuclear factor erythroid derived - 2; HO: 1 Hemeoxygenase; PPARY: Peroxisome proliferator activated receptor gamma; NF- $\boldsymbol{\varkappa B}$ : Nuclear factorkappa B; TNF- $\alpha$ : Tumour necrosis factor alpha IL-1 $\beta$ - interleukin-1beta; C. Decidua: Capparis decidua; ALT: Alkaline transaminase; AST: Aspartate Transaminase; ALP: Alkaline Phosphatase; MDA: Malondialdehyde; GST: Glutathione S Transferase; GPx: Glutathione peroxidase; GR: Glutathione reductase.

\section{REFERENCES}

1. Shanmugasundaram, Venkataraman S. Hepatoprotective and antioxidant effects of Hygrophila auriculata (K. Schum) Heine Acanthaceae root extract. Journal of Ethnopharmacology. 2006;104:(1-2):124-8. 
2. Mahmoud AM. Hesperidin protects against cyclophosphamide-induced hepatotoxicity by upregulation of PPARY and abrogation of oxidative stress and inflammation. Can J Physiol Pharmacol. 2014;92(9):717-24.

3. Kaplowitz S, Win TA, Than ZX, Liu LD. Targeting signal transduction pathways which regulate necrosis in acetaminophen hepatotoxicity. J Hepatol. 2015;63(1):5-7.

4. Larson AM, Polson J, Fontana RJ, Davern TJE, Lalani LS, Hynan JS, et al. Acetaminophen-induced acute liver failure: Results of a United States multicenter, prospective study, Hepatology. 2005;42(6):1364-72.

5. Akacha A, Rebai T, Zourgui L, Amri M. Preventive effect of ethanolic extract of cactus (Opuntiaficus-indica) cladodes on methotrexate-induced oxidative damage of the small intestine in Wistar rats. J Can Res Ther. 2018;14(S3):779-84.

6. Widemann BC, et al. High-dose methotrexate-induced nephrotoxicity in patients with osteosarcoma, incidence, treatment and outcome. Cancer. 2004;100(10):2222-32.

7. Ayad MW, EINaggar AA, EINaggar M. MTHFR C677T polymorphism: Association with lymphoid neoplasm and effect on methotrexate therapy. Eur J Haematol. 2014;93(1):163-9.

8. Sakthiswary, Suresh E. Methotrexate in systemic lupus erythematosus: A systematic review of its efficacy, Lupus. 2014;23(3):225-35.

9. Zhu, Deng FY, Mo XB, Qiu YH, Lei SF. Pharmacogenetics and pharmacogenomics for rheumatoid arthritis responsiveness to methotrexate treatment: The 2013 update. Pharmacogenomics. 2014;15(4):551-66.

10. JrRoenigk $\mathrm{HH}$, Auerbach $\mathrm{R}$, Maibach $\mathrm{H}$, Weinstein $\mathrm{G}$, Lebwohl $M$. Methotrexate in psoriasis: Consensus conference. J Am Acad Dermatol. 1998;38(3):478-85.

11. Akshay, Won KCA, William S, Wing-Kin S. Methotrexate hepatotoxicity and the impact of nonalcoholic fatty liver disease. Am J Med Sci. 2017;354(2):17281.

12. Mahmoud AM, Hozayen WG, Ramadan SM. Berberine ameliorates methotrexate-induced liver injury by activating Nrf2/HO-1 pathway and PPARyamma and suppressing oxidative stress and apoptosis in rats. Biomedicine and pharmacotherapy Biomedecine and Pharmacotherapie. 2017b;94:280-91.

13. Mahmoud AM, Hussein OE, Hozayen WG, Abd El-Twab SM. Methotrexate hepatotoxicity is associated with oxidative stress and down-regulation of PPARyamma and Nrf2: Protective effect of 18 beta-glycyrrhetinic acid. Chem Biol Interact. 2017c;270:59-72.

14. Mahmoud AM, Hussein OE, Hozayen WG, El-Twab ASM. Methotrexate hepatotoxicity is associated with oxidative stress and down-regulation of PPARyamma and Nrf2: Protective effect of 18beta-glycyrrhetinic acid. Chem Biol Interact. 2017;270:59-72.

15. Kolli VK, Natarajan K, Isaac BD, Selvakumar PA. Mitochondrial dysfunction and respiratory chain defects in a rodent model of methotrexate- induced enteritis. Hum Exp Toxicol. 2014;33(10):1051-65.

16. Naik SR, Panda VS. Antioxidant and hepatoprotective effects of Ginkgo bilobaphytosomes in carbon tetrachloride-induced liver injury in rodents. Liver Int. 2007;27(3):393-9.

17. Uraz S, Tahan V, Aygun C, Eren F, Unluguzel G, Yuksel M, et al. Role of ursodeoxycholic acid in prevention of methotrexate-induced liver toxicity. Dig Dis Sci. 2008;53(4):1071-7.

18. Kang MI, Kobayashi AN, Wakabayashi SG, Kim MY. Scaffolding of Keap1 to the actin cytoskeleton controls the function of Nrf2 as key regulator of Cytoprotective phase 2 genes. Proc Natl Acad Sci USA. 2004;101(7):204651.

19. Satta S, Mahmoud AM, Wilkinson FL, Yvonne AM, White SJ. The role of Nrf2 in cardiovascular function and disease. Oxid Med Cell Longev. 2017

20. Mahmoud AM, Germoush MO, Al-Anazi KM, Mahmoud AH, Farah MA, Allam AA. Commiphoramolmol protects against methotrexateinduced nephrotoxicity by up-regulating Nrf2/are/ho-1 signaling. Biomed Pharmacother. 2018;106:499-509.

21. Mahmoud AM, Germoush MO, Soliman AS. Berberine attenuates isoniazid-induced hepatotoxicity by modulating peroxisome proliferatoractivated receptor $\mathrm{g}$, oxidative stress and inflammation. Int $\mathrm{J}$ Pharmacol. 2014;10(8):451-60.

22. Mahmoud AM, Germoush MO, Alotaibi MF, Hussein OE. Possible involvement of Nrf2 and PPARyamma up-regulation in the protective effect of umbelliferone against cyclophosphamide-induced hepatotoxicity. Biomed Pharmacother. 2017;86:297-306.

23. Okuno $\mathrm{Y}$, Matsuda M, Miyata $\mathrm{Y}$, Fukuhara A, Komuro R, Shimabukuro M, et al. Human catalase gene is regulated by peroxisome proliferator activated receptor-gamma through a response element distinct from that of a mouse. Endocr J. 2010;57(4):303-9.

24. Shrishailappa B, Desai VB, Suresh B. Ethnopharmacolgoy, its relevance and need in India. Eastern Pharma. ;64:35-8.

25. Nizar T, Walid E, Ezzeddine S, Abdelhamid K, Saida T, Nizar N. The caper (Capparis L.): Ethnopharmacology, phytochemical and pharmacological properties. Fitoterapia. 2011;82(2):93-101.

26. Upadhyay RK, Ahmad S, Tripathi R, Rohtagi L, Jain SC. Screening of antimicrobial potential of extracts and pure compounds isolated from Capparis decidua. J Med Plants Res. 2010;4(6):439-45.

27. Ali SA, Al-Amin TH, Mohamed AH, Gameel AA. Hepatoprotective activity of aqueous and methanolic extracts of Capparis decidua stems against carbon tetrachloride induced liver damage in rats. J Pharmacol Toxicol. 2009;4(4):167-72.

28. Preetha S, Anitharoy SR. In vitro Antibacterial, free radical scavenging activity of aqueous and ethanolic extract of Capparis decidua. International Journal of Pharmaceutical Research. 2020;1:2988-94.

29. Zourgui L, Akacha A, Rebai T, Amri M. Preventive effect of ethanolic extract of cactus (Opuntiaficus-indica) cladodes on methotrexate-induced oxidative damage of the small intestine in Wistar rats. Journal of Cancer Research and Therapeutics. 2018;14(10):779.

30. Chahlia N. Evaluation of Hypolipidemic Activity of Capparis decidua. Int J Biomed Sci. 2009;5(1):70-3.

31. Ramezannezhad P, Nouri A, Heidarian E. Silymarin mitigates diclofenacinduced liver toxicity through inhibition of inflammation and oxidative stress in male rats. Journal of Herbmed Pharmacology. 2019;8(3):231-7.

32. Devasagayam TPA, Tarachand $U$. Decreased lipid peroxidation in the rat kidney during gestation. Biochemical and Biophysical Research Communications. 1987;145(1):134-8.

33. Pick E, Keisari Y. Superoxide anion and $\mathrm{H}_{2} \mathrm{O}_{2}$ production by chemically elicited peritoneal macrophages-induction by multiple nonphagocytic stimuli. Cell Immunol. 1981;59:301-18.

34. Puntarulo S, Cederbaum Al. Comparison of the ability of ferric complexes to catalyze microsomal chemiluminescence, lipid peroxidation and hydroxyl radical generation. Archives of Biochemistry and Biophysics. 1988;264(2):482-91.

35. Rotruck J, Pope A, Ganther H, et al. Selenium: Biochemical role as a component of glutathione peroxidase. Science. 1973;179(4073):588-90.

36. Habig W, Pabst M, Jakoby W. Glutathione S-transferases. The first enzymatic step in mercapturic acid formation. J Biol Chem. 1974;249(22):7130-9.

37. Staal GE, Visser J, Veeger C. Purification and properties of glutathione reductase of human erythrocytes. Biochim Biophys Acta-ezymol. 1969;185(1):39-48.

38. Saeed M, Iman F, Mahdi E, Habib G, Hadi K, Mehdi G. Hepatoprotective effect of berberine against methotrexate induced liver toxicity in rats. Biomedicine and Pharmacotherapy. 2018;97:233-9.

39. Herfarth $\mathrm{HH}$. Methotrexate for inflammatory bowel diseases: New developments. Dig Dis. 2016;34(1-2):140-6.

40. Ali S, Rashid S, Nafees SK, Hasan A, Shahid F, Majed SS. Protective effect of chlorogenic acid against methotrexate induced oxidative stress, inflammation and apoptosis in rat liver: An experimental approach. Chem Biol Interact. 2017;272:80-91.

41. Ali , Rashid S, Nafees S, Hasan SK, Sultana S. Beneficial effects of Chrysin against Methotrexate-induced hepatotoxicity via attenuation of oxidative stress and apoptosis. Mol Cell Biochem. 2014;385(1-2):215-23.

42. El-Twab ASM, Hozayen WG, Hussein OE, Mahmoud AM. $18 \beta$-glycyrrhetinic acid protects against methotrexate-induced kidney injury by up-regulating the Nrf2/are/ho-1 pathway and endogenous antioxidants. Ren Fail. 2016;38(9):1516-27.

43. Mahmoud AM, Germoush MO, Al-Anazi KM, Mahmoud AH, Farah MA, Allam AA. Commiphoramolmol protects against methotrexateinduced nephrotoxicity by up-regulating Nrf2/are/ho-1 signaling. Biomed Pharmacother. 2018;106:499-509. 
44. Abdalrahman AA, ElTigani S, Sakina Y. Biological activity of extracts from Capparis decidua L. twigs. Journal of Medicinal Plant Research. 2016;10(1):17.

45. Yadav P, Sarkar S, Bhatnagar D. Action of Capparis decidua against alloxaninduced oxidative stress and diabetes in rat tissues. Pharmacological Research. 1997;36(3):221-8.

46. Çakır T, Özkan E, Dulundu E, Topaloğlu Ü, Şehirli AÖ, Ercan F, et al. Caffeic acid phenethyl ester (CAPE) prevents methotrexate-induced hepatorenal oxidative injury in rats. J Pharm Pharmacol. 2011;63(12):1566-71.

47. Vardi N, Parlakpinar H, Cetin A, Erdogan A, Cetin OI. Protectiveeffect of betacarotene on methotrexate-induced oxidative liver damage. Toxicol Pathol. 2010;38(4):592-7.

48. Vardi N, Parlakpinar H, Ates B. Beneficial effects of chlorogenic acid on methotrexate-induced cerebellar Purkinje cell damage in rats. J Chem Neuroanat. 2012;43(1):43-7.

49. Babiak RMV, Campello AP, Carnieri EG, Oliveira M, Benigna M. Methotrexate: Pentose cycle and oxidative stress. Cell Biochemistry and Function. 1998;16(4):283-93.
50. Lipid peroxidation and antioxidant enzymes in erythrocytes and tissues in aged diabetic rats. Yadav P, Sarkar S, Bhatnagar D. Indian J Exp Biol. 1997;35(4):389-92.

51. Leemans JC, Kors LHJ, Florquin S. Pattern recognition receptors and the inflammasome in kidney disease. Nat Rev Nephrol. 2014;10(7):398-414.

52. Mona SM, Hassan SK, Muddathir AK, Siddiquiand NA, Mohd A. A novel germacranolide sesquiterpene lactone with anti-inflammatory effect from Capparis decidua (forsk.) IJRPC. 2012;2(4):1073-7.

53. Mahmoud AM, AIDera HS. 18b-Glycyrrhetinic acid exerts protective effects against cyclophosphamide-induced hepatotoxicity: potential role of PPARY and Nrf2 upregulation. Genes Nutr. 2015;10(6):1-13.

54. Abdella M, Mahmoud AM, El-Derby AM. Brown seaweeds protect against azoxymethane-induced hepatic repercussions through up-regulation of peroxisome proliferator activated receptor gamma and attenuation of oxidative stress. Pharm Biol. 2016;54(11):2496-504.

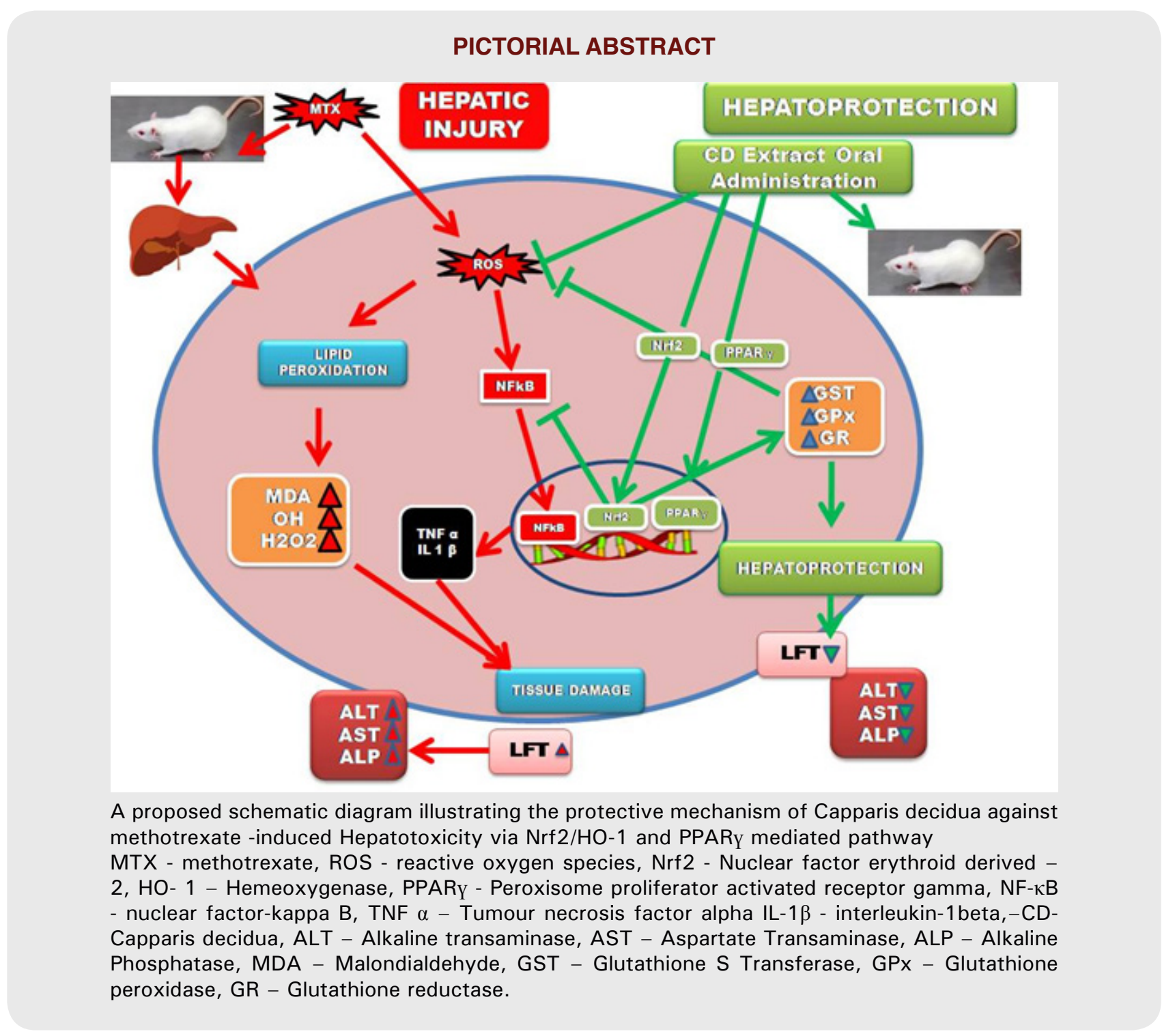




\section{SUMMARY}

- Capparis decidua, a very important medicinal plant of India which is used in traditional system of medicine.

- The study shows that the ethanolic extract of Capparis deciduas fruit being a rich source of antioxidants confers protective effects against lipid peroxidation, oxidative stress, inflammation induced by methotrexate.

- This could be due to the presence of alkaloids, flavonoids, terpenoids, glycosides present in the extract which act as natural antioxidants.

- Hepatoprotective property of the fruit could be via activation of Nrf2,/HO-1 and PPARY signaling pathways.

\section{About Authors}

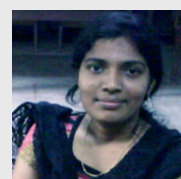

Dr. Preetha. S, is currently working as a Senior Lecturer in the Department of Physiology, Saveetha Dental College and Hospitals, Saveetha Institute of Medical and Technical Sciences Chennai, Tamil Nadu and Pursuing Ph.D from Saveetha Institute of Medical and Technical Sciences. She has published many papers in peer reviewed reputed journals.

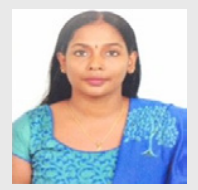

Dr. Anitha Roy, has completed her M. Pharm from Dr. Hari Singh Gour Vishwa Vidyalaya, Sagar, MP and Ph.D (Medical Pharmacology) from Saveetha Institute of Medical and Technical Sciences. She is Currently working as a Associate Professor in the Department of Pharmacology, Saveetha Dental College and Hospitals, Chennai. She has published many papers in peer reviewed reputed journals

Dr. Karthik Ganesh. M, has completed his Master and Doctoral degree in Human Anatomy (Faculty of Medicine) from Dr. ALM. PGIBMS, University of Madras, Chennai. He is currently working as a Assistant professor in the Department of Anatomy, and Scientist, Biomedical Research Unit and Lab Animal Centre, Saveetha Dental College and Hospitals, Chennai. He is currently guiding 4 Ph.D students. He has published many papers in peer reviewed reputed journals

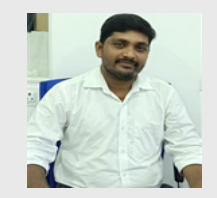

Dr. J. Selvaraj has completed his Ph.D in Endocrinology at Dr. ALM PGIBMS, University of Madras and has 12 years of research experience in Diabetology and Cancer. He is currently working as a Associate Professor in the Department of Biochemistry, and Saveetha Dental College and Hospitals, Chennai. His research contributions have been appreciated by DST-SERB, Government India major research funded projects (Rs. 69 Lakh). He has been awarded several fellowships like UGC-JRF, CSIR-SRF and UGC-PDF etc. He has published several research papers in journals of reputes and guiding 5 Ph.D. students

Cite this article: Preetha S, Roy A, Ganesh MK, Selvaraj J, Rajkumar D. Ethanolic Extract of Capparis decidua Fruit Ameliorates Methotrexate-Induced Hepatotoxicity by Activating Nrf2/HO-1 and PPARY Mediated Pathways. Indian $\mathrm{J}$ of Pharmaceutical Education and Research. 2021;55(1s):s265-s274. 